\title{
2．顎関節症滑液中細胞からの破骨細胞誘導
}

高野 裕史 (九歯大·再建外科)

本研究では, 顎関節症患者の滑液中より細胞を単離, 培養し, 破骨細胞誘導とその分化支持能について検討した. 顎関節滑液は関節洗浄療法により採取し, 得られた細胞から破骨細胞を誘導した。破骨細胞は TRAP 陽性で, 骨吸収 能を有していた。また，培養にて得られた線維芽細胞様細胞はRANKL の発現が認められ，単球との共培養において 破骨細胞が誘導された。ささらに顎関節症滑液中では SRANKL 量が上昇していた．以上より，顎関節滑液中細胞には 破骨細胞への分化能とその支持能を有する細胞が存在し，顎関節症では破骨細胞が誘導されうる環境であることが明 らかとなり，顎関節疾患の病態形成に関与する可能性が示唆された。

\section{Induction of osteoclast-like cells derived from the synovial lavage fluids of patients with temporo- mandibular joint disorders}

Hiroshi Takano (Division of Oral and Maxillofacial Reconstructive Surgery, Kyushu Dental College)

In this study, we induced and characterized osteoclast-like cells from the synovial fluid (SF) of patients with temporomandibular joint (TMJ) disorders (TMDs) and investigated the participation of these cells in the pathogenesis of TMD. We collected SF cells from patients with TMD after a pumping procedure. Osteoclast-like cells were induced from the SF cells of patients with TMD by adding recombinant human $\mathrm{M}-\mathrm{CSF}$ and either $1,25(\mathrm{OH})_{2} \mathrm{D}_{3}$ or $\mathrm{PGE}_{2}$. These cells were positive for TRAP and had the ability to absorb bone. RANKL mRNA was up-regulated on the fibroblastic cells from the SF of TMD patients. Detection of sRANKL in SF of TMD patients was significantly higher than the control. These results suggest that the joint-infiltrating SF cells from TMD patients play important roles in the pathogenesis of these disorders, which is characterized by progressive bone destruction or remodeling.

\section{3. 歯科恐怖症患者における情動と痛みの関連についての臨床的検討}

坂本 英治（九歯大·侵襲制御）

本研究では歯科恐怖症（Dental Phobia 以下 DP）患者に関連する情動変化を捉え，特に痛みとの関連を検討した。 その結果うつ傾向では認めなかったが不安, 特に状態不安では群間に有意な差を認めた。そこで抗不安薬タンドスピ ロンを用いた場合，治療直前の不安の高まりは認めなかった，またこの不安の高まりを抑制するとともに痛みも軽減 され，これは健常者と同程度であった．DP 患者は歯科治療に直面すると顕著に高まる不安のため健常者よりあ痛み を強く感じ，その結果様々な臨床症状を引き起こされるものと推測される．この高まる不安を抑制することで受ける 痛みも軽減されることが示唆された。

\section{Correlation between emotion and pain in patients with dental phobia: a clinical study}

Eiji Sakamoto (Division of Dental Anesthesiology, Kyushu Dental College)

Patients often enter clinical situations feeling a variety of emotions. The aim of this study was to evaluate the correlation between pain and emotions such as anxiety and depression. Emotions were evaluated using a questionnaire and the pain for venipuncture was assessed using a visual analogue scale (VAS-pain). The VAS-pain increased significantly with regards to the degree of anxiety, but not with depression. Furthermore, the needling pain was significantly lower in the group which applied the $5-\mathrm{HT}_{\mathrm{IA}}$ agonist tandospirone citrate as an anxiolytic agent. This study demonstrates that anxiety amplifies pain in patients with dental phobia. These results suggest that the suppression of patient anxiety could also lead to the reduction of pain. 